OPEN ACCESS

Edited by: Matthew Savoca,

Stanford University, United States

Reviewed by:

Dorothy Horn, Portland State University,

United States

André Ricardo Araújo Lima, Center for Marine and Environmental

Sciences (MARE), Portugal

${ }^{*}$ Correspondence:

Susanne Menden-Deuer smenden@uri.edu

Specialty section:

This article was submitted to Marine Pollution,

a section of the journal

Frontiers in Marine Science

Received: 28 May 2021

Accepted: 12 July 2021

Published: 12 August 2021

Citation:

Fulfer VM and Menden-Deuer S (2021) Heterotrophic Dinoflagellate Growth and Grazing Rates Reduced

by Microplastic Ingestion.

Front. Mar. Sci. 8:716349.

doi: 10.3389/fmars.2021.716349

\section{Heterotrophic Dinoflagellate Growth and Grazing Rates Reduced by Microplastic Ingestion}

\author{
Victoria M. Fulfer and Susanne Menden-Deuer* \\ Graduate School of Oceanography, University of Rhode Island, Narragansett, RI, United States
}

Microplastics are ubiquitous contaminants in marine ecosystems worldwide, threatening fisheries production, food safety, and human health. Ingestion of microplastics by fish and large zooplankton has been documented, but there are few studies focusing on single-celled marine predators, including heterotrophic dinoflagellates. In laboratory experiments, the heterotrophic dinoflagellate species Oxyrrhis marina and Gyrodinium sp. readily ingested both algal prey and polystyrene microplastic spheres $(2.5-4.5 \mu \mathrm{m})$, while Protoperidinium sp. did not ingest microplastics. Compared to algae-only fed dinoflagellates, those that ingested microplastics had growth rates reduced by 25$35 \%$ over the course of 5 days. Reduced growth resulted in a $30-50 \%$ reduction of secondary production as measured as predator biomass. Ingestion rates of algal prey were also reduced in the microplastic treatments. When given a mixture of microplastics and algal prey, O. marina displayed a higher selectivity for algal prey than Gyrodinium sp. Observations in the coastal ocean showed that phylogenetically diverse taxa ingested microplastic beads, and thus heterotrophic dinoflagellates could contribute to trophic transfer of microplastics to higher trophic levels. The results of this study may suggest that continued increase in microplastic pollution in the ocean could lead to reduced secondary production of heterotrophic protists due to microplastic ingestion, altering the flow of energy and matter in marine microbial food webs.

\footnotetext{
Keywords: microplastic pollution, heterotrophic dinoflagellate, plastic ingestion, planktonic food web, trophic transfer
}

\section{INTRODUCTION}

Plastic pollution in the ocean has become a leading environmental issue, threatening food safety, coastal tourism, fisheries and aquaculture stocks and ultimately human health (Thevenon et al., 2015; IUCN, 2018; De-la-Torre, 2020). Microplastic particles, from $1 \mu \mathrm{m}$ to $5 \mathrm{~mm}$ in size, are part of the growing number of abundant and persistent pollutants in the ocean, but the potential effects these particles have on the health of marine organisms are only beginning to be investigated (Andrady, 2011; Rochman et al., 2013; Eriksen et al., 2014; Worm et al., 2017).

Prior studies have shown that plastics are ingested and egested by copepods and other multicellular zooplankton (Frost, 1977; Cole et al., 2013, 2015; Setälä et al., 2014), benthic invertebrates (Al-Sid-Cheikh et al., 2018; Redondo-Hasselerharm et al., 2018), and fish (Lu et al., 2016). Direct ingestion of microplastics by copepods in the laboratory resulted in energetic deficiencies, reduction of grazing and hatching success, and even in death (Cole et al., 2013, 2015). 
Microzooplankton, which are less than $200 \mu \mathrm{m}$ in size, are responsible for removing the majority of phytoplankton in the ocean, exceeding grazing by copepods and other large zooplankton (Sherr and Sherr, 2002; Calbet and Landry, 2004; Calbet, 2008). Microzooplankton, such as ciliates and heterotrophic dinoflagellates, are predominantly fed on by mesozooplankton, consequently funneling energy from primary production to higher trophic levels. Thus, microzooplankton serve as a trophic link between the microbial loop and classic ocean food web (Calbet and Saiz, 2005; Steinberg and Landry, 2017).

Heterotrophic dinoflagellates are microzooplankton that have been shown to play a central role in pelagic food webs, and thus changes in their abundance and physiological rates can have implications for ocean ecosystem functioning (Sherr and Sherr, 1994; Jeong et al., 2010; Caron and Hutchins, 2013). Heterotrophic dinoflagellates often outnumber other microzooplankton and consume a greater proportion of bloomforming diatoms than copepods and mesozooplankton, play a critical role in phenomena such as the North Atlantic spring bloom and subsequent export production (Sherr and Sherr, 2007).

Despite their ecological importance, there is little quantitative data available on grazing by heterotrophic dinoflagellates on microplastics. Given their diverse feeding strategies, dinoflagellates are likely candidates to ingest microplastics, due to the microplastics' similar size and shape compared to algal prey. Since the presence of microplastics has been shown to adversely affect growth and photosynthesis in phototrophic dinoflagellates (Zhao et al., 2019; Su et al., 2020), presence and possible ingestion of microplastics could similarly reduce growth and secondary production of heterotrophic dinoflagellates. While it is unknown if heterotrophic dinoflagellates retain microplastics in their cells over time or pass on only what has been recently ingested, it is clear there is potential for bioaccumulation and trophic transfer of microplastics to higher trophic levels (Setälä et al., 2014; Athey et al., 2020). If microplastics are retained and accumulated within dinoflagellate cells, this may lead to biomagnification, thus exacerbating the impact of microplastics on dinoflagellates and higher trophic levels. Given the known negative consequences of plastic ingestion for copepods (Cole et al., 2013, 2015), entry of microplastics into marine microbial food webs could have far-reaching implications for marine food webs.

Despite many attempts to quantify the abundance of microplastics in the surface ocean globally, the concentration of plastics smaller than $5 \mu \mathrm{m}$ is not well known and varies widely from dilute to concentrated in coastal areas with high input from coastal runoff and accumulation in gyres (Eriksen et al., 2014; van Sebille et al., 2015). As this study was designed as a scientific proof of concept, microplastic concentrations exceeding those observed in the environment today were used to determine if heterotrophic dinoflagellates with diverse feeding types could ingest microplastic particles, and if the effect of this ingestion could be quantified in the laboratory. Concentrations were not chosen to reflect in situ concentrations of microplastic particles.

Understanding the effect of microplastics on grazing rates is imperative for predicting how the presence and inevitable increase of microplastics in the ocean could affect food web dynamics, trophic transfer, and fisheries production. To address this knowledge gap, the objectives of this study were to (1) investigate if microplastics are ingested by marine heterotrophic dinoflagellate species, (2) quantify heterotrophic dinoflagellate grazing rates when exposed to microplastics, and (3) determine if ingestion of microplastics affects heterotrophic dinoflagellate growth rates and secondary production. These questions were examined on three heterotrophic dinoflagellate species (e.g., Oxyrrhis marina; Gyrodinium sp.; Protoperidinium bipes) in a laboratory setting. Finally, to examine if microplastic particle ingestion could be observed in diverse taxa in whole plankton community incubations in the coastal ocean, communities of zooplankton in natural seawater samples taken from the Northeast Atlantic Shelf waters were incubated in the presence of microplastics.

\section{MATERIALS AND METHODS}

Clonal cultures of Oxyrrhis marina (SPMC 107), Gyrodinium sp. (PA200810) and Protoperidinium bipes (South Korea) were established by single cell isolation. $O$. marina is identical to the culture used in Anderson and Menden-Deuer (2017). Gyrodinium sp. was isolated from Narragansett Bay, RI in 2010 and P. bipes is identical to the culture used in Schuech and Susanne Menden-Deuer (2014). All three species of heterotrophic dinoflagellates average $14-20 \mu \mathrm{m}$ in size (Franzè and Menden-Deuer, 2020). Heterotrophic dinoflagellates were fed the prymnesiophyte Isochrysis galbana (CCMP 1323) cultured in $\mathrm{f} / 2-\mathrm{Si}$ medium and transferred once a week to maintain exponential growth (Guillard, 1975). All cultures were maintained in $125 \mathrm{~mL}$ polycarbonate (PC) flasks on a $12 \mathrm{~h}: 12 \mathrm{~h}$ light-dark cycle at $15^{\circ} \mathrm{C}$ and a salinity of 31.4 psu. Predators were incubated at a light intensity of 8-15 $\mu \mathrm{mol}$ photons $\mathrm{m}^{-2} \mathrm{~s}^{-1}$, while prey were incubated at a light intensity of $70-80 \mu \mathrm{mol}$ photons $\mathrm{m}^{-2} \mathrm{~s}^{-1}$.

Fluorescent yellow polystyrene (PS) microplastic particles ranging in diameter from 2.5 to $4.5 \mu \mathrm{m}$ were used in all microplastic feeding experiments (Spherotech, FP-3052-2). This size range was chosen to mimic the size of the chosen algal prey species, as verified by microscopy (3-6 $\mu \mathrm{m}$ ) (Menden-Deuer et al., 2020). Microplastic particles were rinsed three times in DI water and resuspended in autoclaved, $0.2 \mu \mathrm{m}$ filtered seawater directly before use.

Two experiment types were chosen for this study: (1) longterm experiments lasting 5 days to measure the effect of microplastic ingestion on growth and grazing; and (2) short-term experiments lasting up to $4 \mathrm{~h}$ to establish the functional response of heterotrophic dinoflagellates and determine the potential for selectivity between algal prey and microplastic particles. We chose the duration of our experiments in accordance with the time scales for heterotrophic protist growth and grazing rates, which have measurable effects over days and hours, respectively. While grazing, or ingestion, is instantaneous, the ramifications in terms of growth, and thus secondary production, take time 
to accumulate and often can be delayed to times scales of days (Landry and Calbet, 2004; Anderson and Menden-Deuer, 2017).

\section{Long-Term Growth and Grazing Experiments}

The possibility and subsequent effects of microplastic ingestion by heterotrophic dinoflagellate species were determined using two treatment conditions: first, an algae-only treatment, in which heterotrophic dinoflagellates were fed algal prey; and second, a treatment with microplastics, in which heterotrophic dinoflagellates were fed a mixture of algal prey and microplastic particles. Here, we consider microplastic particles as a potential non-natural prey item. Each experiment exposed each heterotrophic dinoflagellate species separately to prey treatments to avoid inducing competition between predator species. For each experiment, prey control treatments were prepared in triplicate in $125 \mathrm{~mL}$ polycarbonate bottles with I. galbana diluted in filtered seawater (FSW) to a final concentration of 70,000100,000 prey cells $\mathrm{mL}^{-1}$. This control was used to calculate the growth rate of algal prey in the absence of grazing, which is necessary for the calculation of ingestion rates (Frost, 1972).

All treatments were prepared in triplicate and in a total volume of $125 \mathrm{~mL}$ and incubated in $250 \mathrm{~mL}$ polycarbonate bottles on a $12 \mathrm{~h}: 12 \mathrm{~h}$ light-dark cycle at $15^{\circ} \mathrm{C}$ and a light intensity of 8-15 $\mu \mathrm{mol}$ photons $\mathrm{m}^{-2} \mathrm{~s}^{-1}$ on a shaker table at 60 rotationsper-minute (rpm) to reduce settling of microplastic particles. Each of the target heterotrophic dinoflagellate species was separately incubated with I. galbana and microplastic particles, when applicable, diluted in $0.2 \mu \mathrm{m}$ filtered and autoclaved seawater (FSW) to the chosen concentrations (see Table 1). High concentrations of microplastics exceeding current environmental observations were used to induce a high dinoflagellate encounter rate of both algal prey and microplastics.

Microplastic spiked experiments were run for 5 days and sampled daily. For each treatment, heterotrophic dinoflagellates were fed algal prey, or a mixture of microplastics and algal prey, at $\mathrm{T} 0$, and not fed again for the duration of the experiment. Samples of $3 \mathrm{~mL}$ were taken daily and fixed with $10 \%$ glutaraldehyde to a final concentration of $0.1 \%$ glutaraldehyde. Fixed samples were used to count heterotrophic dinoflagellates via light microscopy. Epifluorescence microscopy was used to verify plastic ingestion by dinoflagellate cells. To measure growth and ingestion rates, subsamples of $10 \mathrm{~mL}$ were taken at T0 and every $24 \mathrm{~h}$ for 5 days. Abundances of prey, predators, and microplastic particles were measured with a Beckman Coulter Multisizer 3 (Beckman Coulter) using a $100 \mu \mathrm{m}$ aperture.

All statistical analyses were performed in $\mathrm{R}$ (version 1.4.1106). The maximum abundances of heterotrophic dinoflagellates reached in each treatment were used as a first-order quantification of secondary production. Specific growth rates of prey, in the I. galbana control, and heterotrophic dinoflagellates, in all experimental treatments, were calculated by a linear regression of natural log-transformed abundance through time (ggpmisc; Aphalo, 2021). Growth rates of heterotrophic dinoflagellates were calculated over the time span for which exponential growth occurred in the algal-only treatments, days 0-4 for O. marina and days 1-5 for Gyrodinium sp. The slope of the line fit through the natural log-transformed abundance data for the given time range denotes the growth rate.

Ingestion rates (I) were calculated via Equation 1 (Frost, 1972),

$$
I=\frac{\left(N_{i^{*}} e^{\mu}\right)-N_{f}}{P} / t
$$

where $N_{i}$ and $N_{f}$ refer to the initial and final concentration of prey, respectively, as measured via the Coulter Counter. The growth rate $(\mu)$ is calculated as described above from the predator-free I. galbana control. P is the geometric mean of the zooplankton concentration, and $t$ is the duration. Ingestion rates of plastic were calculated in the same manner, based on the initial and final plastic concentrations.

\section{Short-Term Functional Response and Selectivity Experiments}

The functional responses of $O$. marina and Gyrodinium sp. were investigated in short-term experiments lasting 3-4 h. The goal of this second set of experiments was to determine whether microplastics and prey were ingested at the same rate, or if dinoflagellates displayed a preference for either prey or microplastics, hereafter referred to as a "selectivity factor."

The two dinoflagellate species that were found to ingest microplastics were separately subjected to two treatments: an algal prey only treatment and a treatment containing a 1:1 ratio of algal prey and microplastic particles. Total prey particle concentrations were equal between treatments at the start of

TABLE 1 | Initial (TO) and final (T5) abundances $\left(\mathrm{mL}^{-1}\right)$ of heterotrophic dinoflagellates, algal prey, and microplastics in each treatment of the 5-day microplastic ingestion experiments.

\begin{tabular}{|c|c|c|c|c|}
\hline Treatment & \multicolumn{2}{|c|}{ Algae-only } & \multicolumn{2}{|c|}{ Algal prey + microplastics } \\
\hline \multicolumn{5}{|l|}{ O. marina } \\
\hline Algal prey & $158,466 \pm 1,930$ & $7,977 \pm 1,070$ & $155,000 \pm 4,180$ & $53,674 \pm 2,474$ \\
\hline Microplastics & 0 & 0 & $86,431 \pm 2,840$ & $42,092 \pm 2,691$ \\
\hline Algal prey & $153,750 \pm 4,420$ & $9,478 \pm 4,073$ & $144,433 \pm 3,707$ & $40,921 \pm 1,953$ \\
\hline Microplastics & 0 & 0 & $111,230 \pm 5,371$ & $83,534 \pm 1,768$ \\
\hline
\end{tabular}


the experiment. Here, "total particles" will refer to the sum of all potential prey items, microplastics and algae. Thus, in the algae-only treatment, total particle abundance and abundance of algae are equal. In the algal prey and microplastics treatment, the total particle abundance is equal to the sum of algal prey and microplastic particles.

A total of 13-15 concentrations of algal prey and microplastics were chosen to create a geometric spread of total possible prey particles (algal prey + microplastics) between 4,000 and 270,000 prey particles $\mathrm{mL}^{-1}$ (Berges et al., 1994; see Supplementary Table 1). For example, O. marina was prepared in 30 bottles, with 15 bottles containing the concentration gradient of algae, and the other 15 bottles containing the chosen array of combined algal prey and microplastics concentrations. The same was carried out for Gyrodinium sp. Each treatment contained 900-1,100 cells $\mathrm{mL}^{-1}$ of $O$. marina or $500-800$ cells $\mathrm{mL}^{-1}$ of Gyrodinium sp. and was prepared to a final volume of $125 \mathrm{~mL}$.

Samples of $10 \mathrm{~mL}$ were taken at time 0 and after $3 \mathrm{~h}$. The initial and final abundances of microplastic particles, prey, and heterotrophic dinoflagellates were measured with a $100 \mu \mathrm{m}$ aperture on a Beckman Coulter Multisizer 3 (Beckman Coulter). Heterotrophic dinoflagellate concentrations were chosen as all particles between 10 and $20 \mu \mathrm{m}$ in size and verified by microscopy (Menden-Deuer et al., 2020). Concentrations of microplastic particles and algal cells overlapped at their upper and lower size ranges, respectively, and thus were determined using a mixture model (Friendly, 2021), and verified via microscopy.

Ingestion rates as a function of the prey concentration or the combined prey and microplastic concentration fit a Holling Type II relationship, equivalent to a Michaelis-Menten dependency (Michaelis and Menten, 1913; Monod, 1949; Holling, 1965) (Equation 2).

$$
F(N)=\frac{a N P}{1+a h N P}
$$

In Equation 2, $\mathrm{F}(\mathrm{N})$ is the ingestion rate, $a$ is the attack rate, $h$ is the handling time, $N$ is the prey abundance, and $P$ is the predator abundance. $N$ and $P$ were measured using the Coulter Counter and used to calculate the ingestion rate $[\mathrm{F}(\mathrm{N})]$ with Equation 1. A non-linear least squares model (nls) in R (lsmeans; Lenth, 2016) was used to iteratively solve for $a$ and $h$ given the experimental data. Then, the best fit curve was modeled using the functional response experimental data and a non-linear least squares model (nls) in R (lsmeans; Lenth, 2016), which iteratively determined the best fit curve by minimizing the sum of the squared residuals between the model values for the response and the experimental data. The model inputs included the average starting abundance of heterotrophic dinoflagellates, which was 970 cells $\mathrm{mL}^{-1}$ for O. marina and 632 cells $\mathrm{mL}^{-1}$ for Gyrodinium sp., and prey concentrations ranging from 0 to 300,000 cells $\mathrm{mL}^{-1}$.

A selectivity factor for each species was calculated using a linear regression analysis between plastic ingestion rates and prey ingestion rates. Ingestion rates of plastic and of prey were calculated using Equation 1. The selectivity factor, or slope of the line, could range from 0 to 1 , with zero indicating no uptake of less-preferred prey or high selectivity, and 1 indicating equal uptake of all particle types reflecting no selectivity at all.

Two-way ANOVA analyses were completed on ingestion rates or growth rates using time, treatment, and species as effects (AICcmodavg; Mazerolle, 2020). Time was included as a categorical factor (i.e., T0, T1, etc.). Time was included in the ANOVA analysis to avoid confounding effects, as it was known that ingestion rates would vary with time as algal concentrations were depleted, but this variation in time would not be identical between treatments. When significant interactions between effects were observed ( $p<0.05$ ), Tukey's HSD post hoc tests were carried out to identify the associated treatment factors.

\section{Microplastic Ingestion in Coastal Communities}

The presence of microplastic particles on uptake in microzooplankton within whole plankton communities were tested using microplastic addition experiments conducted on two scientific cruises aboard the $R / V$ Endeavor, EN657 in October 2020 and EN661 in January 2021. Both cruises followed the Northeast Shelf Long-term Ecological Time Series (NES-LTER) cruise track from Narragansett Bay, RI to the edge of the Northeast Atlantic continental shelf. Rates of phytoplankton growth and microzooplankton grazing were quantified using the two-point dilution method (Landry and Hassett, 1982; Morison and Menden-Deuer, 2017). On each cruise, samples were collected following Marrec et al. (2021). Samples were spiked with 1,000 fluorescent yellow polystyrene (PS) microplastic particles $\mathrm{mL}^{-1}(2.5-4.5 \mu \mathrm{m}$ in size) and incubated for $24 \mathrm{~h}$ in deckboard surface seawater flow-through incubators. Fluorescent microplastic particles were chosen to avoid detection of potential contaminants present in the seawater. Concentrations of microplastics were chosen to ensure detectability of the plastic particles and do not reflect realistic concentrations of microplastics in the surface ocean.

Once $24 \mathrm{~h}$ had elapsed, samples for organism and plastic particle imaging were taken and fixed with glutaraldehyde to a final concentration of $0.1 \%$. Microscopy slides were prepared using a primuline yellow stain (Caron, 1983) to dye the phytoplankton and zooplankton cells and analyzed via epifluorescence microscopy for the identification of zooplankton phyla with and without microplastic ingestion.

\section{RESULTS}

\section{Long Term Growth and Grazing Experiments}

When fed a mixture of algal prey and microplastic particles, two of the three heterotrophic dinoflagellate species were able to ingest microplastics. When viewed under light and epifluorescence microscopy, both Gyrodinium sp. and O. marina cells contained ingested fluorescent microplastic particles (Figure 1), while no $P$. bipes cells were found to have microplastic particles ingested. For the remainder of this study, we will focus on the description of results pertaining to O. marina and Gyrodinium sp. 

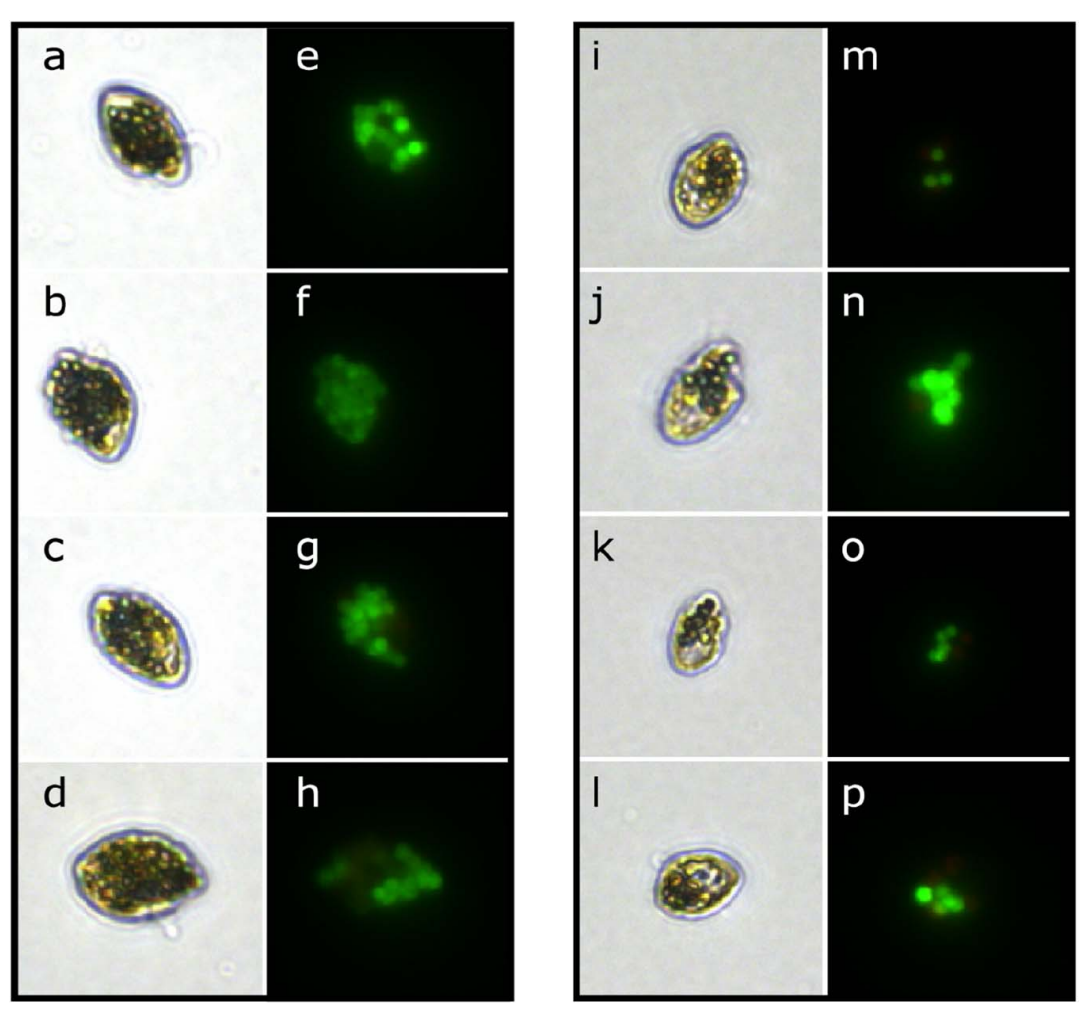

FIGURE 1 | Micrographs of the heterotrophic dinoflagellates O. marina (left column) and Gyrodinium sp. (right column) with microplastic beads (fluorescent green) ingested under light (a-d,i-l) and epifluorescence (e-h,m-p) illumination.

\section{Growth Rates}

Over the 5-day experiment, both O. marina and Gyrodinium sp. reached higher abundances in algae-only treatments than treatments with microplastics (Figure 2). Both a diet of algal prey only and a diet of combined microplastics and algal prey elicited positive growth rates in O. marina and Gyrodinium sp. (Figure 3). For both heterotrophic dinoflagellate species, growth was slower in the treatment with microplastics, which subsequently resulted in a reduction in secondary production.

O. marina had a $25 \%$ slower maximum growth rate in the presence of microplastics $\left(0.43 \pm 0.04 \mathrm{~d}^{-1}\right)$ compared to when fed only algae $\left(0.60 \pm 0.03 \mathrm{~d}^{-1}, p=0.004\right)$ (Table 2). This reduction in dinoflagellate growth rates led to a cell abundance average of just over 2,800 cells $\mathrm{mL}^{-1}$ by day 5 of the experiment in the microplastic-fed treatments. This is an accumulation almost $30 \%$ lower in the microplastics treatment than in the algae-only treatment, which reached nearly 4,000 cells $\mathrm{mL}^{-1}$.

Gyrodinium sp. reached a maximum growth rate of $0.40 \pm 0.04 \mathrm{~d}^{-1}$ in the algae-only treatment (Table 2). Gyrodinium sp. reached a lower maximum growth rate of $0.27 \pm 0.07 \mathrm{~d}^{-1}$ in the treatment with microplastics, growing on average $35 \%$ slower than in the algae-only treatment $(p=0.047)$. This reduced growth rate led to a reduced dinoflagellate accumulation. By day 5 of the experiment, Gyrodinium sp. cell abundances in the treatment with microplastics were $46 \%$, or nearly half, of the cell abundances in algae-only treatment.
A two-way ANOVA for both species confirmed that growth rates were statistically different across time $(p=0.0001)$ and between treatments $(p=0.0004)$. Thus, the negative effect of microplastics on growth rates was significant.

\section{Ingestion Rates Over Time}

Over the course of the 5-day experiment, each treatment was fed only at day 0 , allowing the observation of ingestion rates over time in a closed system. O. marina had an average ingestion rate of $62 \pm 7$ cells predator $^{-1}$ day $^{-1}$ in the algae-only treatment and an average ingestion rate of $37 \pm 5$ cells predator $^{-1}$ day $^{-1}$ in the treatment with microplastics. O. marina in the algae-only treatment reached a maximum ingestion rate of $164 \pm 15$ cells predator $^{-1}$ day $^{-1}$ on day 2 , at which point the ingestion rate was over twice as high as in the treatment with microplastics on the same day (ingestion $=67 \pm 10$ cells predator $^{-1}$ day $^{-1}$ on day 2) and nearly double the maximum ingestion rate reached over the course of the treatment with microplastics (maximum ingestion $=87 \pm 10$ cells predator ${ }^{-1} \mathrm{day}^{-1}$ ) (Table 2).

Gyrodinium sp. had an average ingestion rate of $45 \pm 8$ cells predator $^{-1}$ day $^{-1}$ in the algae-only treatment and only a slightly

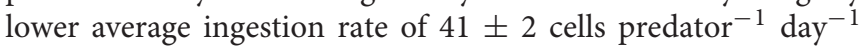
in the treatment with microplastics. Maximum ingestion rates for both treatments were reached on day 1, with a maximum ingestion of $96 \pm 12$ cells predator ${ }^{-1}$ day $^{-1}$ in the algae-only treatment and $114 \pm 11$ cells predator ${ }^{-1}$ day $^{-1}$ in the treatment with microplastics. Except for day one, Gyrodinium sp. ingestion 
A

O. marina

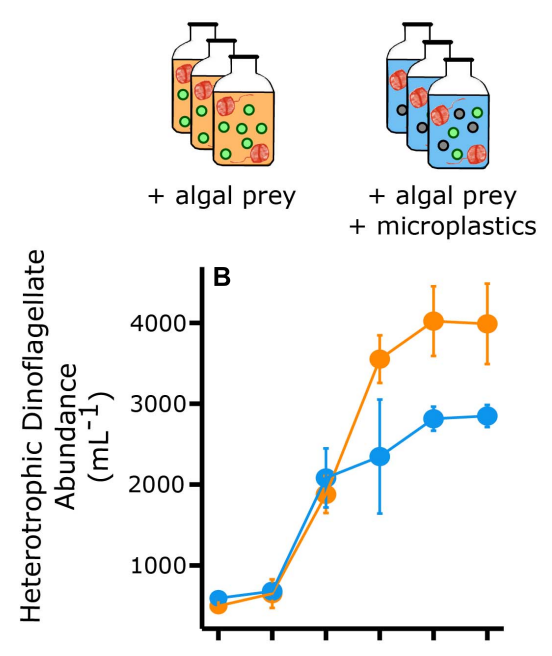

D

\section{Gyrodinium sp.}
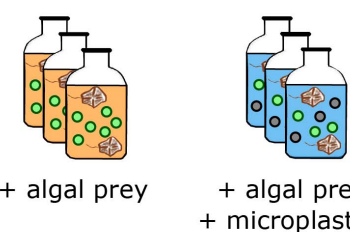

+ algal prey

+ microplastics
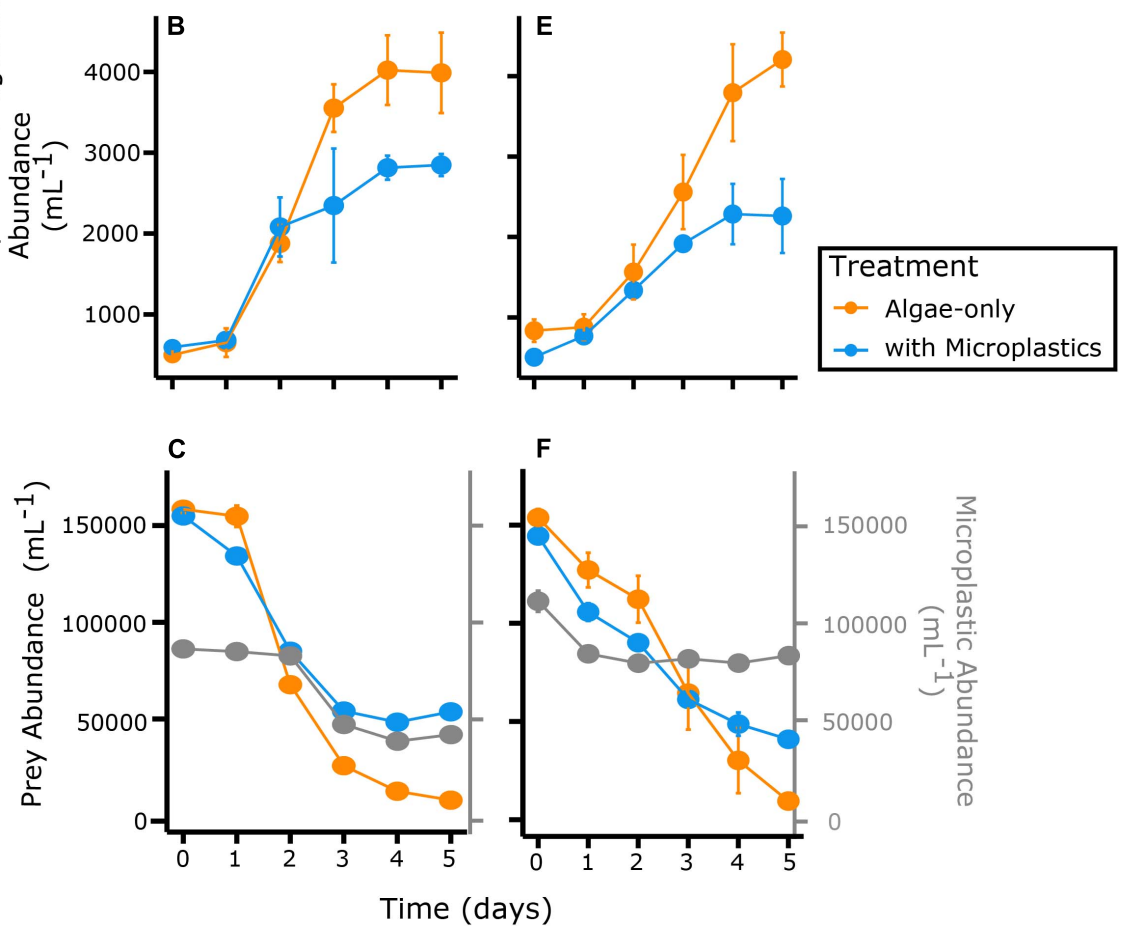

FIGURE 2 | Abundance of heterotrophic dinoflagellates in two feeding treatments, algae only (orange) and a mixture of microplastics with algal prey (blue) over time. The top row shows the experimental setup, with triplicate bottles of each treatment for each species. The second row shows abundance of $O$. marina (A-C) and Gyrodinium sp. (D-F) and third row, abundance of prey and microplastics for the respective predator treatments. Gray points represent the microplastic particle abundance in the treatments with microplastics. Error bars indicate one standard deviation of the mean, which is contained within the symbol for many measurements.

rates on any given day were up to $40 \%$ higher in the algae-only treatment than in the treatment with microplastics.

Over time, diminished prey concentrations resulted in reduced ingestion rates that were not significantly different between treatments. Thus, the effect of microplastics on ingestion rates was significant early in the experiment when total prey particles (algal prey and/or microplastics) were at concentrations greater than 50,000 particles $\mathrm{mL}^{-1}$. ANOVA analyses showed a statistically significant interaction between the effects of time and treatment on ingestion rates of prey by both species of heterotrophic dinoflagellates $(p=0.027)$ (Figure 4). Tukey's HSD post hoc tests confirmed that, for both dinoflagellate species, ingestion rates were statistically different across time and between treatments for day $2(p=0.0054)$, when total prey particles were abundant enough to yield high grazing rates.

\section{Short-Term Functional Response and Selectivity Experiments}

The short-term experiments with only algae or with a 1:1 mixture of microplastics and prey showed a typical Type II functional response, with ingestion rates increasing up to a saturating prey density in both species of dinoflagellates (Figure 5).

$O$. marina functional responses differed between the two treatments. Maximum ingestion rates by $O$. marina with microplastics ( 7.1 cells predator ${ }^{-1} \mathrm{~h}^{-1}$ ) were reduced by nearly $50 \%$ when compared to the algae-only treatment $(13.8$ cells predator $\left.^{-1} \mathrm{~h}^{-1}\right)$. The treatment with microplastics reached an overall maximum ingestion rate of all particle types (algae and microplastics) of 9.4 particles predator ${ }^{-1} \mathrm{~h}^{-1}$. O. marina was found to have a selectivity factor of 0.203 between the two treatments across all prey concentrations, 


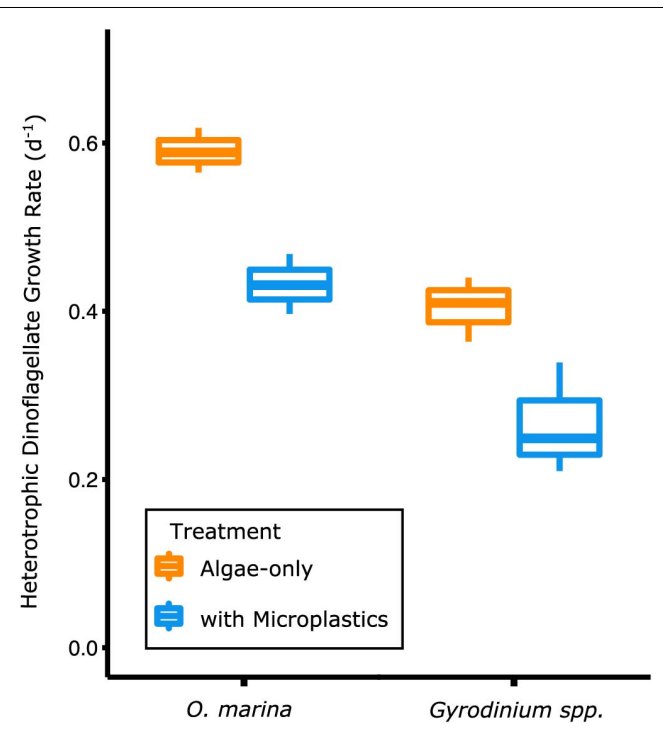

FIGURE 3 | Heterotrophic dinoflagellate growth rates during the exponential growth phase were higher when dinoflagellates were fed only algal prey (orange) and lower when fed a mixture of algal prey and microplastics (blue). The box plot shows median, the 25th-75th percentiles, and error bars as the $95 \%$ confidence interval.

TABLE 2 | Average growth rates (day ${ }^{-1}$ ), average ingestion rates of algal prey (cells predator ${ }^{-1}$ day $^{-1}$ ), and maximum ingestion rates of algal prey (cells predator $^{-1}$ day $^{-1}$ ) reached in each treatment of the long-term growth and grazing experiments.

\begin{tabular}{|c|c|c|}
\hline & Algae-only & Algal prey + Microplastics \\
\hline \multicolumn{3}{|l|}{ O. marina } \\
\hline Average growth rate $\left(\right.$ day $\left.^{-1}\right)$ & $0.60 \pm 0.03$ & $0.43 \pm 0.04$ \\
\hline $\begin{array}{l}\text { Average ingestion rate (Cells } \\
\text { predator }^{-1} \text { day }^{-1} \text { ) }\end{array}$ & $62 \pm 7$ & $37 \pm 5$ \\
\hline $\begin{array}{l}\text { Maximum ingestion rate (Cells } \\
\text { predator }^{-1} \text { day }^{-1} \text { ) }\end{array}$ & $164 \pm 15$ & $87 \pm 10$ \\
\hline \multicolumn{3}{|l|}{ Gyrodinium sp. } \\
\hline Average growth rate $\left(\right.$ day $\left.^{-1}\right)$ & $0.40 \pm 0.04$ & $0.27 \pm 0.07$ \\
\hline $\begin{array}{l}\text { Average ingestion rate (cells } \\
\text { predator }^{-1} \text { day }^{-1} \text { ) }\end{array}$ & $45 \pm 8$ & $41 \pm 2$ \\
\hline $\begin{array}{l}\text { Maximum ingestion rate (cells } \\
\text { predator }^{-1} \text { day }^{-1} \text { ) }\end{array}$ & $96 \pm 12$ & $114 \pm 11$ \\
\hline
\end{tabular}

indicating high selectivity of algal prey compared to microplastic particles (Figure 5C).

As seen with the ingestion rates, there was less selectivity against microplastic particles for Gyrodinium sp. The functional responses of Gyrodinium sp. were relatively similar between the two treatments. The heterotrophic dinoflagellates in the algaeonly treatment reached a maximum ingestion rate of 10 cells predator ${ }^{-1} \mathrm{~h}^{-1}$. The treatment with microplastics reached a maximum ingestion rate of algae of 7.4 cells predator ${ }^{-1} \mathrm{~h}^{-1}$, and an overall maximum ingestion rate of all particle types of 12 particles predator ${ }^{-1} \mathrm{~h}^{-1}$. When comparing overall prey ingestion rate to plastic ingestion rate, a selectivity factor of 0.662 was observed.

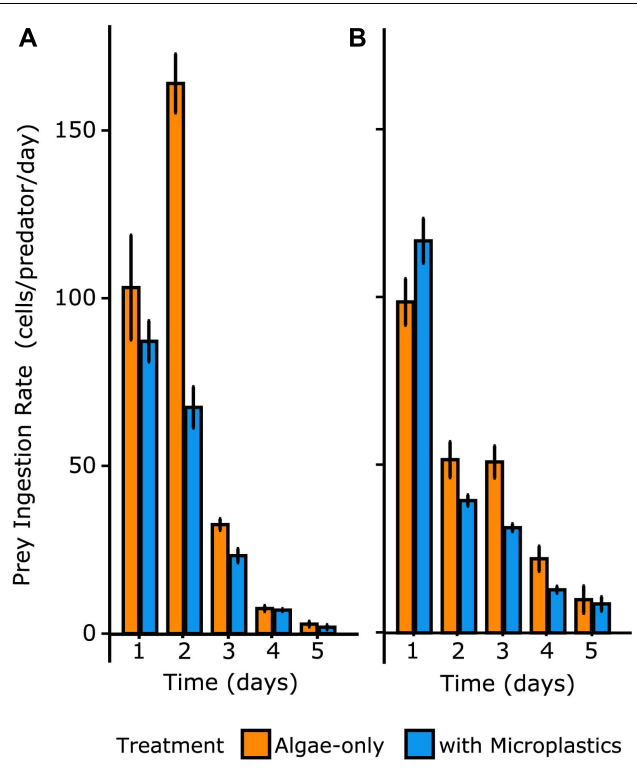

FIGURE 4 | Ingestion rates of algal prey through time over 5 days for O. marina (A) and Gyrodinium sp. (B) Irrespective of treatment, ingestion rate decreased over time with decreasing prey particle concentration. Error bars indicate one standard deviation of the mean.

Concentrations of microplastics ranged from 2,000 to 110,000 particles $\mathrm{mL}^{-1}$, and ingestion of microplastics was observed even at low concentrations by both heterotrophic dinoflagellate species. When prey and microplastics were at equal concentrations, Gyrodinium sp. consumed, on average, 2 microplastic particles for every 3 algal prey consumed. On the other hand, O. marina had a much higher selectivity factor, and on average consumed 1 microplastic particle for every 5 algal prey ingested. Both dinoflagellate species reached similar maximum ingestion rates of algal prey in the treatment with microplastics, despite $O$. marina's higher ingestion rates when fed only algal prey. When algal prey was abundant, heterotrophic dinoflagellates preferentially selected for algae, but at lower total particle concentrations microplastics and prey were ingested at more similar rates.

\section{Microplastic Ingestion in Coastal Communities}

When coastal water communities from the Northeast Atlantic Shelf were incubated in the presence of microplastic particles for $24 \mathrm{~h}$, ingestion was confirmed in several organisms. Plankton taxa with confirmed microplastic ingestion included many of the mixotrophic dinoflagellates of the genus Ceratium and ciliates (Figure 6).

\section{DISCUSSION}

The aim of this study was to assess and quantify the ingestion of microplastic particles by marine heterotrophic dinoflagellates and examine subsequent effects on feeding ecology and 
A

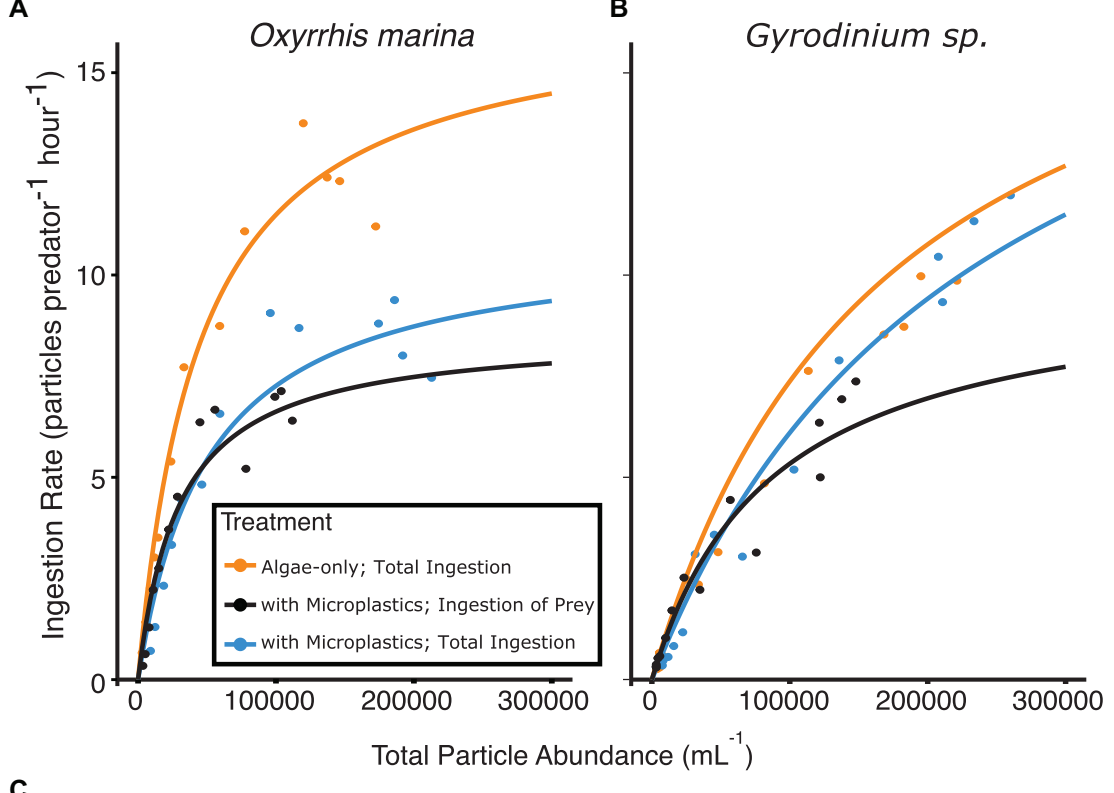

C

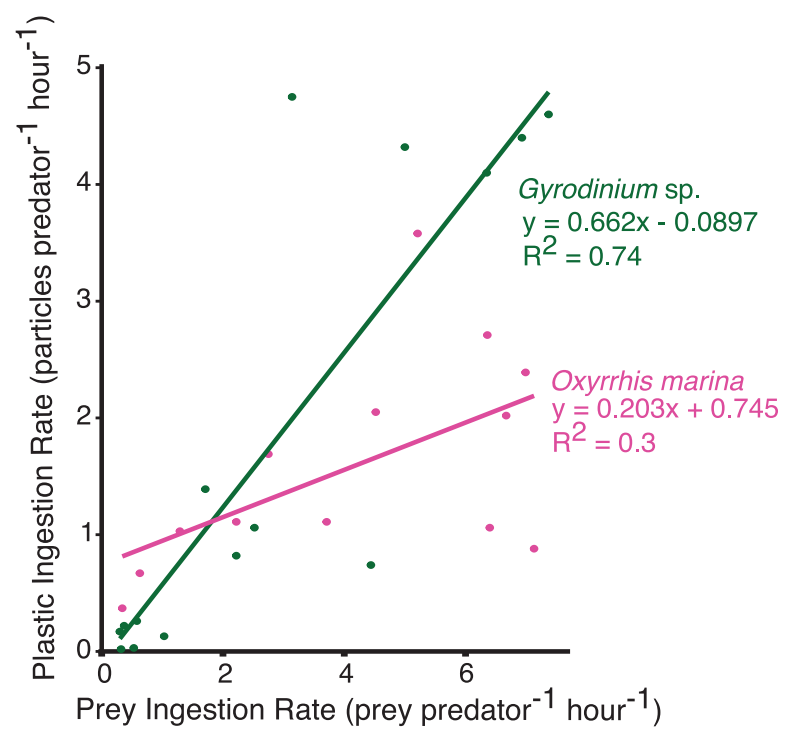

FIGURE 5 | Functional response curves from short-term, $3 \mathrm{~h}$ feeding experiments, fit to the ingestion rate and total particle abundances for (A) 0 . marina and (B) Gyrodinium sp. fed algal prey, or a mixture of algal prey and microplastics. Ingestion rates of algal prey (orange and black) as well as total ingestion of all particle types present (orange and blue) are shown for comparison. The relationship between the rate of plastic ingestion and rate of prey ingestion (C) when both prey types are at equal concentrations reveals the selectivity factor of each species between microplastic particles and algal prey. O. marina (C, pink) showed higher selectivity for prey than Gyrodinium sp. (C, green).

secondary production. Although it has been established that zooplankton ingest microplastics (Cole et al., 2013), here we show that large quantities of microplastic particles have the potential to enter the marine food web via heterotrophic dinoflagellates. Our findings for direct ingestion of microplastic particles by heterotrophic dinoflagellates are in agreement with previous zooplankton studies using bacterivorous microflagellates (Nygaard et al., 1988) as well as other microzooplankton and mesozooplankton grazers (Cole et al., 2013; Setälä et al., 2014; Athey et al., 2020). Both O. marina and Gyrodinium sp. ingested plastic at high rates. On the other hand, $P$. bipes was unable to ingest microplastics. P. bipes is a pallium feeder, where the cell envelopes and digests prey in an external pseudopod known as a pallium (Gaines and Taylor, 1984; Jacobson and Anderson, 1986; Gribble et al., 2007). Due to this unique feeding strategy, it was not surprising that this particular species did not ingest microplastics. These results indicate that many, but not all, other dinoflagellate species could also readily ingest plastic particles in the same size range as their algal prey. 


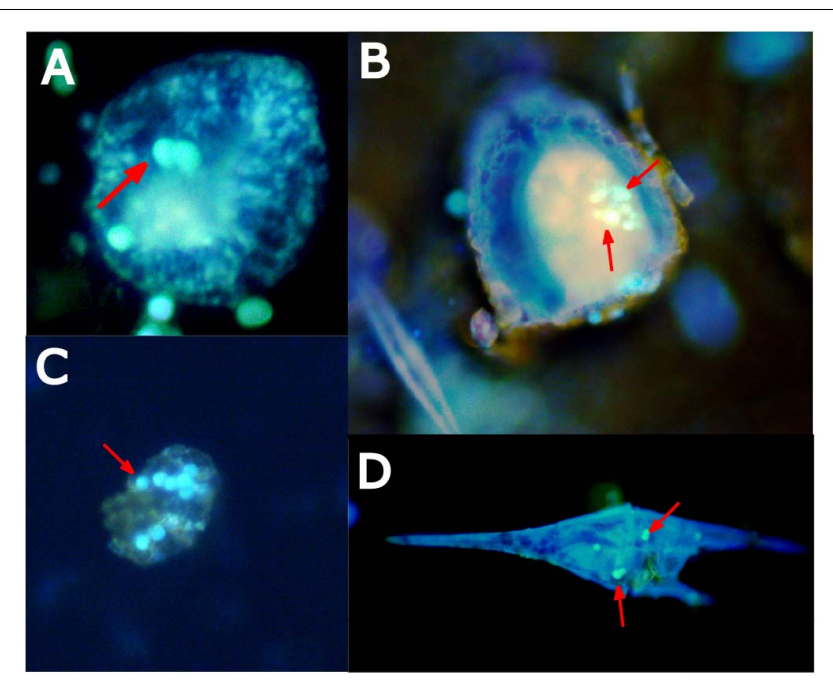

FIGURE 6 | Epifluorescence microscopy images of coastal marine microplankton, such as ciliates (A,B), dinoflagellates (C), and Ceratium (D), stained with primuline dye with confirmed microplastic ingestion (fluorescent spheres denoted by red arrows) after 24-h of exposure.

Ingestion of plastic resulted in reduced growth for both O. marina and Gyrodinium sp. For both species, a reduction in maximum growth rate of approximately 30\% was observed between the algae-only and microplastics treatments. Growth rates of these species have been reported in the range of $0.05-$ 1.2 day $^{-1}$, with increasing prey availability inducing a hyperbolic response in growth rates (Anderson and Menden-Deuer, 2017). Thus, the microplastics-induced reduction in growth rate is on par with a 2-4-fold reduction in prey availability for Gyrodinium sp. and O. marina, respectively.

Heterotrophic protists are important components of mesozooplankton nutrition (Stoecker and Capuzzo, 1990; Calbet and Saiz, 2005; Sherr and Sherr, 2007). Beyond predation by mesozooplankton, marine dinoflagellates are also fed on by other dinoflagellates, ciliates, larvae of mussels and larval fish (Lasker et al., 1970; Scura and Jerde, 1977; Berggreen et al., 1988; Hansen, 1991). The reduced growth rates due to microplastic ingestion led to a reduced accumulation of heterotrophic dinoflagellates, with abundances in the treatment with microplastics between 30 and $50 \%$ lower than those in the algae-only treatments. This significant reduction in secondary production could have far-reaching implications on trophic transfer, prey availability for higher trophic levels and marine microbial community structure, as the impairment of unicellular zooplankton growth will mean fewer grazers to prey upon phytoplankton biomass (Franks, 2001; Calbet, 2008; Vallina et al., 2014). Reduced secondary production curtails the trophic transfer of primary production to higher trophic levels, which could fundamentally alter the structure and function of planktonic marine food webs by causing a bottom-up cascade effect of reduced population sizes up the food chain. The weakening of this link between the microbial food web and the classical food chain could have implications for fisheries production.
We did not observe that plastic particles were egested, but the overall abundance of microplastics did not increase once initially depleted. This indicates that microplastics were either rapidly ingested and egested, or that egestion was not occurring. The retention and potential accumulation of microplastic particles in dinoflagellates opens the possibility of trophic transfer of biomagnified plastics from the bottom of the food web up to the broad range of consumers of heterotrophic dinoflagellates, including the potential bioaccumulation of plastics in fish and larger predators (Athey et al., 2020). A direct link for such trophic transfer of microplastics could be from dinoflagellates to anchovy larvae, as some mixotrophic dinoflagellates are critical components in the larval diet (Lasker, 1975; Scura and Jerde, 1977; Wroblewski, 1984).

Ingestion of plastic differed between species and was dependent on the plastic concentration and the concurrent availability of algal prey. It is well-established that the rate at which heterotrophic dinoflagellates ingest algae is dependent on prey availability (Kimmance et al., 2006). Over the course of the 5 -day experiment, microplastic ingestion by $O$. marina led to an average reduction in algal ingestion rate of $60 \%$ when compared to the algae-only treatment. In contrast, Gyrodinium sp. ingestion rates for both treatments were, on average, within $10 \%$ of each other. Larger zooplankton, such as copepods, have shown a reduction in algal ingestion rates when exposed to microplastics with a $45-75 \%$ reduction in ingestion rates observed between treatments with microplastics and those fed only algal prey (Cole et al., 2013).

Both O. marina and Gyrodinium sp. showed some level of discrimination between microplastics and algal prey. Our results indicate that $O$. marina, with a selectivity factor of 0.203 , preferentially consumed algal prey when presented with prey and microplastic particle mixtures at sufficiently high concentrations. Gyrodinium sp., with a selectivity factor of 0.662 , indicated less selectivity between ingesting an algal cell or a microplastic particle. Reduced selectivity means that Gyrodinium sp. would likely remove more microplastics from the environment. Prey selectivity is well documented among algal species (Hansen, 1992; Meunier et al., 2012; Guo et al., 2013) and our work documents that at least one species of heterotrophic dinoflagellate can discriminate against microplastic particles. This implies that although presence of microplastics can be disruptive to heterotrophic dinoflagellate secondary production, the capacity of predators for selectivity could ameliorate plastics uptake. Thus, going forward, a strict, concentration-dependent and proportional uptake of microplastics is not to be expected.

The ability of some heterotrophic dinoflagellates to ingest plastics is not surprising, given the broad range of prey types for microzooplankton, including other non-living items such as marine snow aggregates (Shanks and Walters, 1996) and crude oil droplets (Almeda et al., 2014). Studies show heterotrophic dinoflagellates may have a preference for living prey emitting biochemical signals (Wootton et al., 2006; Guo et al., 2013). Microplastic particles used in this study were not colonized by bacterial biofilms due to being rinsed and transferred into seawater only minutes before addition to the experiment. However, it should be noted that bacterial colonization of 
microplastics in the environment could increase ingestion by zooplankton (Vroom et al., 2017). In the ocean, microplastics are rapidly colonized and biofilms form (Muthukumar et al., 2011; Carson et al., 2013). Such colonization could facilitate decreased predator selectivity, and potentially enhanced uptake of microplastics, making our rate estimates conservative. Moreover, studies have shown that marine plastic debris acquires a chemical signature while it is in the photic zone, which can increase feeding by anchovy and seabirds (Savoca et al., 2016, 2017). Thus, feeding on uncolonized, unaltered microplastics as used here likely represents a conservative estimate of feeding rates and could be enhanced when these particles acquire a chemical signature that draws zooplankton to plastic particles.

While this study was conducted under controlled laboratory conditions, preliminary results do indicate that microplastic ingestion in whole plankton communities from the coastal ocean can occur across diverse phyla. These findings align with recent studies on zooplankton taxa, including copepods and ciliates (Cole et al., 2013, 2015; Athey et al., 2020) and confirm that these laboratory results could be applicable to the complex conditions in the coastal ocean.

This study utilized microplastic concentrations higher than those currently found in ocean waters in order to create high encounter rates between heterotrophic dinoflagellates and microplastic particles. With the current trends in plastic production, and with 8 million tons of plastic waste entering the ocean each year (Jambeck et al., 2015), these high concentrations of microplastics smaller than $5 \mu \mathrm{m}$ are not out of the question in a future ocean. Microplastic abundance in the ocean is expected to increase as larger plastics are fragmented into microplastic particles (Thompson, 2015). At the same time, despite the recognition of the plastic pollution problem, and efforts to ban some plastic products, plastic production has been increasing steadily, from 5 million tons each year in the 1950s, to over 300 million tons a year today (Thompson et al., 2009; PlasticsEurope, 2011; Law, 2017). While the microplastic concentrations in this study vastly exceeded current estimated concentrations of larger microplastics in each ocean basin (Eriksen et al., 2014; van Sebille et al., 2015), these estimates do not include microplastics smaller than $300 \mu \mathrm{m}$. Therefore, the concentration of small microplastics available for ingestion by heterotrophic dinoflagellates is an important unknown.

Overall, the results of this study are important when determining the potential effects microplastic pollution can have on plankton communities in areas of high plastic contamination, particularly coastal waters. Heterotrophic dinoflagellate growth and ingestion of algal prey was significantly and considerably (at least 30\%) reduced when exposed to microplastic particles. If these processes are in effect in whole plankton communities under natural conditions, they would result in unrealized productivity for higher trophic levels and alterations to the abundance and composition of planktonic communities. Marine

\section{REFERENCES}

Almeda, R., Connelly, T. L., and Buskey, E. J. (2014). Novel insight into the role of heterotrophic dinoflagellates in the fate of crude oil at sea. Sci. Rep. $4: 7560$. plastic pollution is a global problem and incorporating measures of the effect of microplastic pollution on the growth and ingestion rates of microzooplankton species, and their ramifications for food web structure and production, will be critical in tracking how the effects of plastic pollution could radiate from heterotrophic dinoflagellates at the base of the food web all the way up through the fishing and aquaculture industry, and their effects on marine productivity.

\section{DATA AVAILABILITY STATEMENT}

The datasets presented in this study have been submitted to the Biological and Chemical Oceanography Data Management Office (BCO-DMO) under the project Quantifying Temperature Dependence in Growth and Grazing Rates of Planktonic Herbivores (OCE-1736635). https://www.bco-dmo.org/project/ 739232.

\section{AUTHOR CONTRIBUTIONS}

VF and SM-D collaborated on the inception of the project idea and experimental design. VF carried out experiments and data analysis and prepared the initial draft of the manuscript. Both authors contributed to the article and approved the submitted version.

\section{FUNDING}

This work was supported by the grants from National Science Foundation, Biological Oceanography OCE-1736635. Further support came from grants for the North East Shelf Long Term Ecological Research project (NES-LTER) (1655686) and under the EPSCoR Research Infrastructure Improvement Award (\#OIA-1655221).

\section{ACKNOWLEDGMENTS}

We thank Jason Schaedler and Dawn Outram for culturing and logistical support, respectively. We thank Jacob Strock and Heather McNair for help with experimental design and valuable feedback. We are grateful to the reviewers and editor for their comments that improved this manuscript.

\section{SUPPLEMENTARY MATERIAL}

The Supplementary Material for this article can be found online at: https://www.frontiersin.org/articles/10.3389/fmars. 2021.716349/full\#supplementary-material

Al-Sid-Cheikh, M., Steve, J. R., Karen, S., Claude, R., Henry, T. B., and Thompson, R. C. (2018). Uptake, whole-body distribution, and depuration of nanoplastics by the scallop Pecten maximus at environmentally realistic concentrations. Environ. Sci. Technol. 52, 14480-14486. doi: 10.1021/acs.est.8b05266 
Anderson, S. R., and Menden-Deuer, S. (2017). Growth, grazing, and starvation survival in three heterotrophic dinoflagellate species. J. Eukaryotic Microbiol. 64, 213-225. doi: 10.1111/jeu.12353

Andrady, A. L. (2011). Microplastics in the marine environment. Mar. Pollut. Bull. 62, 1596-1605. doi: 10.1016/j.marpolbul.2011.05.030

Aphalo, P. J. (2021). ggpmisc: Miscellaneous Extensions to 'ggplot2'. R package version 0.3.8-1. Available Online at: https://CRAN.R-project.org/package= ggpmisc.

Athey, S. N., Albotra, S. D., Gordon, C. A., Monteleone, B., Seaton, P., Andrady, A. L., et al. (2020). Trophic transfer of microplastics in an estuarine food chain and the effects of a sorbed legacy pollutant. Limnol. Oceanogr. Lett. 5, 154-162. doi: 10.1002/lol2.10130

Berges, J. A., Montagnes, D. J. S., Hurd, C. L., and Harrison, P. J. (1994). Fitting ecological and physiological data to rectangular hyperbolae: A comparison of methods using monte carlo simulations. Mar. Ecol. Prog. Ser. 114, 175-183. doi: 10.3354/meps114175

Berggreen, B., Hansen, B., and Kiørboe, T. (1988). Food size spectra, ingestion and growth of the copepod Acartia tonsa during development: implications for determination of copepod production. Mar. Biol. 99, 341-352. doi: 10.1007/ bf02112126

Calbet, A. (2008). The trophic roles of microzooplankton in marine systems. ICES J. Mar. Sci. 65, 325-331. doi: 10.1093/icesjms/fsn013

Calbet, A., and Landry, M. R. (2004). Phytoplankton growth, microzooplankton grazing, and carbon cycling in marine systems. Limnol. Oceanogr. 49, 51-75. doi: $10.4319 / 10.2004 .49 .1 .0051$

Calbet, A., and Saiz, E. (2005). The ciliate-copepod link in marine ecosystems. Aquatic Microb. Ecol. 38, 157-167. doi: 10.3354/ame038157

Caron, D. A. (1983). Technique for enumeration of nanoplankton using epifluorescence microscopy. Appl. Environ. Microbiol. 46, 491-498. doi: 10. 1128/aem.46.2.491-498.1983

Caron, D. A., and Hutchins, D. A. (2013). The effects of changing climate on microzooplankton grazing and community structure: drivers, predictions, and knowledge gaps. J. Plankton Res. 35, 235-252. doi: 10.1093/plankt/fbs091

Carson, H. S., Nerheim, M. S., Carroll, K. A., and Eriksen, M. (2013). The plasticassociated microorganisms of the North Pacific Gyre. Mar. Pollut. Bull. 75, 126-132. doi: 10.1016/j.marpolbul.2013.07.054

Cole, M., Lindeque, P., Fileman, E., Halsband, C., and Galloway, T. S. (2015). The impact of polystyrene microplastics on feeding, function and fecundity in the marine copepod Calanus helgolandicus. Environ. Sci. Technol. 49, 1130-1137. doi: 10.1021/es504525u

Cole, M., Lindeque, P., Fileman, E., Halsband, C., Goodhead, R., Moger, J., et al. (2013). Microplastic ingestion by zooplankton. Environ. Sci. Technol. 47, 6646-6655. doi: 10.1021/es400663f

De-la-Torre, G. E. (2020). Microplastics: an emerging threat to food security and human health. J. Food Sci. Technol. 57, 1601-1608. doi: 10.1007/s13197-01904138- 1

Eriksen, M., Lebreton, L. C., Carson, H. S., Thiel, M., Moore, C. J., Borerro, J. C., et al. (2014). Plastic pollution in the World's oceans: more than 5 trillion plastic pieces weighing over 250,000 tons afloat at sea. PloS One. 9:e111913. doi: 10.1371 /journal.pone.0111913

Franks, P. J. S. (2001). Phytoplankton blooms in a fluctuating environment: the roles of plankton response time scales and grazing. J. Plankton Res. 23, 1433-1441. doi: 10.1093/plankt/23.12.1433

Franzè, G., and Menden-Deuer, S. (2020). Common temperature-growth dependency and acclimation response in three herbivorous protists. Mar. Ecol. Prog. Ser. 634, 1-13. doi: 10.3354/meps 13200

Friendly, M. (2021). vcdExtra: ' $v c d$ ' Extensions and Additions. R Package Version 0.7-5. Available online at: https://CRAN.R-project.org/package=vcdExtra

Frost, B. W. (1972). Effects of size and concentration of food particles on the feeding behavior of the marine planktonic copepod Calanus pacificus. Limnol. Oceanogr. 17, 805-815. doi: 10.4319/lo.1972.17.6.0805

Frost, B. W. (1977). Feeding behavior of Calanus pacificus in mixtures of food particles. Limnol. Oceanogr. 22, 472-491. doi: 10.4319/lo.1977.22.3. 0472

Gaines, G., and Taylor, F. J. R. (1984). Extracellular digestion in marine dinoflagellates. J. Plankton Res. 6, 1057-1061. doi: 10.1093/plankt/6.6.1057

Gribble, K. E., Nolan, G., and Anderson, D. M. (2007). Biodiversity, biogeography and potential trophic impact of protoperidinium Spp. (Dinophyceae) off the
Southwestern Coast of Ireland. J. Plankton Res. 29, 931-947. doi: 10.1093/ plankt/fbm070

Guillard, R. L. (1975). "Culture of Phytoplankton for Feeding Marine Invertebrates," in Culture of Marine Invertebrate Animals: Proceedings - 1st Conference on Culture of Marine Invertebrate Animals Greenport, eds L. S. Walter and M. H. Chanley (Boston, MA: Springer), 29-60. doi: 10.1007/9781-4615-8714-9_3

Guo, Z., Zhang, H., Lui, S., and Lin, S. (2013). Biology of the marine heterotrophic dinoflagellate Oxyrrhis marina: current status and future directions. Microorganisms. 1, 33-57. doi: 10.3390/microorganisms10 10033

Hansen, P. J. (1991). Quantitative importance and trophic role of heterotrophic dinoflagellates in a coastal pelagial food web. Mar. Ecol. Prog. Ser. 73, 253-261. doi: $10.3354 /$ meps 073253

Hansen, P. J. (1992). Prey size selection, feeding rates and growth dynamics of heterotrophic dinoflagellates with special emphasis on Gyrodinium spirale. Mar. Biol. 114, 327-334. doi: 10.1007/bf00349535

Holling, C. S. (1965). The functional response of predators to prey density and its role in mimicry and population regulation. Mem. Entomol. Soc. Can. 97, 5-60. doi: 10.4039/entm9745fv

IUCN. (2018). Marine Plastics. Gland, Switzerland: IUCN.

Jacobson, D. M., and Anderson, D. M. (1986). Thecate heterophic dinoflagellates: feeding behavior and mechanisms. J. Phycol. 22, 249-258. doi: 10.1111/j.15298817.1986.tb00021.x

Jambeck, J. R., Geyer, R., Wilcox, C., Siegler, T. R., Perryman, M., Andrady, A., et al. (2015). Plastic waste inputs from land into the ocean. Science 347, 768-771. doi: $10.1126 /$ science. 1260352

Jeong, H. J., Yoo, Y. D., Kim, J. S., Seong, K. A., Kang, N. S., and Kim, T. H. (2010). Growth, feeding and ecological roles of the mixotrophic and heterotrophic dinoflagellates in marine planktonic food webs. Ocean Sci. J. 45, 65-91. doi: 10.1007/s12601-010-0007-2

Kimmance, S. A., Atkinson, D., and Montagnes, D. J. S. (2006). Do temperaturefood interactions matter? Responses of production and its components in the model heterotrophic flagellate Oxyrrhis marina. Aquatic Microb. Ecol. 42, 63-73. doi: 10.3354/AME042063

Landry, M. R., and Calbet, A. (2004). Microzooplankton production in the oceans. ICES J. Mar. Sci. 61, 501-507. doi: 10.1016/j.icesjms.2004.03.011

Landry, M. R., and Hassett, R. P. (1982). Estimating the grazing impact of marine micro-zooplankton. Mar. Biol. 67, 283-288. doi: 10.1007/bf00397668

Lasker, R. (1975). Field criteria for survival of anchovy larvae: the relation between inshore chlorophyll maximum layers and successful first feeding. Fish. Bull. U.S. 73, 453-462.

Lasker, R., Feder, H. M., Theilacker, G. H., and May, R. C. (1970). Feeding, growth, and survival of Engraulis mordax larvae reared in the laboratory. Mar. Biol. 5, 345-353. doi: 10.1007/BF00346901

Law, K. L. (2017). Plastics in the marine environment. Annu. Rev. Mar. Sci. 9, 205-229.

Lenth, R. V. (2016). Least-Squares Means: The R Package lsmeans. J. Stat. Software 69, 1-33. doi: 10.18637/jss.v069.i01

Lu, Y., Zhang, Y., Deng, Y., Jiang, W., Zhao, Y., Geng, J., et al. (2016). Uptake and accumulation of polystyrene microplastics in Zebrafish (Danio rerio) and toxic effects in liver. Environ. Sci. Technol. 50, 4054-4060. doi: 10.1021/acs.est. $6 \mathrm{~b} 00183$

Marrec, P., Heather, M. N., Gayantonia, F., Françoise, M., Jacob, P. S., and MendenDeuer, S. (2021). Seasonal variability in planktonic food web structure and function of the Northeast U.S. Shelf. Limnol. Oceanogr. 66, 1440-1458. doi: $10.1002 /$ lno.11696

Mazerolle, M. J. (2020). AICcmodavg: Model selection and multimodel inference based on $(Q) A I C(c)$. R package version 2.3-1. Available Online at: https://cran. r-project.org/package $=$ AICcmodavg.

Menden-Deuer, S., Morison, F., Montalbano, A. L., Franzè, G., Strock, J., Rubin, E., et al. (2020). Multi-instrument assessment of phytoplankton abundance and cell sizes in mono-specific laboratory cultures and whole plankton community composition in the North Atlantic. Front. Mar. Sci. 7:254. doi: 10.3389/fmars. 2020.00254

Meunier, C. L., Hantzsche, F. M., Cunha-Dupont, A. Ö, Haafke, J., Oppermann, B., Malzahn, A. M., et al. (2012). Intraspecific selectivity, compensatory feeding and flexible homeostasis in the phagotrophic flagellate Oxyrrhis marina: three 
ways to handle food quality fluctuations. Hydrobiologia 680, 53-62. doi: 10 . 1007/s10750-011-0900-4

Michaelis, L., and Menten, M. L. (1913). Die Kinetik der Invertinwirkung. Biochem. Z. 49, 333-369.

Monod, J. (1949). The growth of bacterial cultures. Annu. Rev. Microbiol. 3, 371-394. doi: 10.1146/annurev.mi.03.100149.002103

Morison, F., and Menden-Deuer, S. (2017). Doing more with less? Balancing sampling resolution and effort in measurements of protistan growth and grazing rates. Limnol. Oceanogr. Methods 15, 794-809. doi: 10.1002/lom3.10200

Muthukumar, T., Aravinthan, A., Lakshmi, K., Venkatesan, R., Vedaprakash, L., and Doble, M. (2011). Fouling and stability of polymers and composites in marine environment. Int. Biodeterior. Biodegradat. 65, 276-284. doi: 10.1016/ j.ibiod.2010.11.012

Nygaard, K., Børsheim, K. Y., and Thingstad, T. F. (1988). Grazing rates on bacteria by marine heterotrophic microflagellates compared to uptake rates of bacterialsized monodisperse fluorescent latex beads. Mar. Ecol. Prog. Ser. 44, 159-165. doi: $10.3354 /$ meps044159

PlasticsEurope. (2011). Plastics the facts 2011. An analysis of European plastics production, demand and recovery for 2010. Belgium: PlasticsEurope, 32.

Redondo-Hasselerharm, P. E., De Ruijter, V. N., Mintenig, S. M., Verschoor, A., and Koelmans, A. A. (2018). Ingestion and chronic effects of car tire tread particles on freshwater Benthic Macroinvertebrates. Environ. Sci. Technol. 52, 13986-13994. doi: 10.1021/acs.est.8b05035

Rochman, C. M., Hoh, E., Kurobe, T., and Teh, S. J. (2013). Ingested plastic transfers hazardous chemicals to fish and induces hepatic stress. Sci. Rep. 3:3263. doi: 10.1038/srep03263

Savoca, M. S., Tyson, C. W., McGill, M., and Slager, C. J. (2017). Odours from marine plastic debris induce food search behaviours in a forage fish. Proc. $R$. Soc. B Biol. Sci. 284:20171000. doi: 10.1098/rspb.2017.1000

Savoca, M. S., Wohlfeil, M. E., Ebeler, S. E., and Nevitt, G. A. (2016). Marine plastic debris emits a keystone infochemical for olfactory foraging seabirds. Sci. Adv. 2:e1600395. doi: 10.1126/sciadv.1600395

Schuech, R., and Menden-Deuer, S. (2014). Going ballistic in the plankton: anisotropic swimming behavior of marine protists. Limnol. Oceanogr. Fluids Environ. 4, 1-16. doi: 10.1215/21573689-2647998

Scura, E. D., and Jerde, C. (1977). Various species of phytoplankton as food for larval northern anchovy, Engraulis mordax, and relative nutritional values of the dinoflagellate Gymnodinuim splendens and Gonyaulax polyedra. Fish Bull. $75,577-583$.

Setälä, O., Fleming-Lehtinen, V., and Lehtiniemi, M. (2014). Ingestion and transfer of microplastics in the planktonic food web. Environ. Pollut. 185, 77-83. doi: 10.1016/j.envpol.2013.10.013

Shanks, A., and Walters, K. (1996). Feeding by a heterotrophic dinoflagellate (Noctiluca scintillans) in marine snow. Limnol. Oceanogr. 41, 177-181. doi: 10.4319/lo.1996.41.1.0177

Sherr, E. B., and Sherr, B. F. (1994). Bacterivory and herbivory: key roles of phagotrophic protists in pelagic food webs. Microb. Ecol. 28, 223-235. doi: 10.1007/BF00166812

Sherr, E. B., and Sherr, B. F. (2002). Significance of predation by protists in aquatic microbial food webs. Antonie van Leeuwenhoek 81, 293-308. doi: 10.1023/A: 1020591307260

Sherr, E. B., and Sherr, B. F. (2007). Heterotrophic dinoflagellates: a significant component of microzooplankton biomass and major grazers of diatoms in the sea. Mar. Ecol. Prog. Ser. 352, 187-197. doi: 10.3354/meps07161

Steinberg, D. K., and Landry, M. R. (2017). Zooplankton and the ocean carbon cycle. Annu. Rev. Mar. Sci. 9, 413-444. doi: 10.1146/annurev-marine-010814015924
Stoecker, D., and Capuzzo, J. M. (1990). Predation on protozoa: its importance to zooplankton. J. Plankton Res. 12, 891-908. doi: 10.1093/plankt/12.5.891

Su, Y., Zhang, K., Zhou, Z., Wang, J., Yang, X., Tang, J., et al. (2020). Microplastic exposure represses the growth of endosymbiotic dinoflagellate Cladocopium goreaui in culture through affecting its apoptosis and metabolism. Chemosphere 244:125485. doi: 10.1016/j.chemosphere.2019.125485

Thevenon, F., Carroll, C., and Sousa, J. (2015). Plastic Debris in the Ocean: The Characterization of Marine Plastics and Their Environmental Impacts, Situation Analysis Report. Gland, Switzerland: IUCN.

Thompson, R. C. (2015). "Microplastics in the Marine Environment: Sources, Consequences and Solutions," in Marine Anthropogenic Litter, eds M. Bergmann, L. Gutow, and M. Klages (Cham: Springer), 185-200. doi: 10.1007/ 978-3-319-16510-3_7

Thompson, R. C., Moore, C., vom Saal, F. S., and Swan, S. H. (2009). Plastics, the environment and human health: current consensus and future trends. Philos. Trans. R. Soc. B. 364, 2153-2166. doi: 10.1098/rstb.2009.0053

Vallina, S. M., Follows, M. J., Dutkiewicz, S., Montoya, J. M., Cermeno, P., and Loreau, M. (2014). Global relationship between phytoplankton diversity and productivity in the ocean. Nat. Commun. 5:4299. doi: 10.1038/ncomms 5299

van Sebille, E., Wilcox, C., Lebreton, L., Maximenko, N., Hardesty, B. D., van Franeker, J. A., et al. (2015). A global inventory of small floating plastic debris. Environ. Res. Lett. 10:124006. doi: 10.1088/1748-9326/10/12/124006

Vroom, R. J. E., Koelmans, A. A., Besseling, E., and Halsband, C. (2017). Aging of microplastics promotes their ingestion by marine zooplankton. Environ. Pollut. 231, 987-996. doi: 10.1016/j.envpol.2017.08.088

Wootton, E. C., Zubkov, M. V., Jones, D. H., Jones, R. H., Martel, C. M., Thornton, C. A., et al. (2006). Biochemical prey recognition by planktonic protozoa. Environ. Microbiol. 9, 216-222. doi: 10.1111/j.1462-2920.2006.01130.x

Worm, B., Lotze, H. K., Jubinville, I., Wilcox, C., and Jambeck, J. (2017). Plastic as a persistent marine pollutant. Annu. Rev. Environ. Resour. 42, 1-26. doi: 10.1146/annurev-environ-102016-060700

Wroblewski, J. S. (1984). Formulation of growth and mortality of larval northern anchovy in a turbulent feeding environment. Mar. Ecol. Prog. Ser. 20, 13-22. doi: 10.3354/meps020013

Zhao, T., Tan, L., Huang, W., and Wang, J. (2019). The interactions between Micro Polyvinyl Chloride (MPVC) and marine dinoflagellate Karenia mikimotoi: the inhibition of growth, chlorophyll and photosynthetic efficiency. Environ. Pollut. 247, 883-889. doi: 10.1016/j.envpol.2019.01.114

Conflict of Interest: The authors declare that the research was conducted in the absence of any commercial or financial relationships that could be construed as a potential conflict of interest.

Publisher's Note: All claims expressed in this article are solely those of the authors and do not necessarily represent those of their affiliated organizations, or those of the publisher, the editors and the reviewers. Any product that may be evaluated in this article, or claim that may be made by its manufacturer, is not guaranteed or endorsed by the publisher.

Copyright (c) 2021 Fulfer and Menden-Deuer. This is an open-access article distributed under the terms of the Creative Commons Attribution License (CC BY). The use, distribution or reproduction in other forums is permitted, provided the original author(s) and the copyright owner(s) are credited and that the original publication in this journal is cited, in accordance with accepted academic practice. No use, distribution or reproduction is permitted which does not comply with these terms. 